\title{
Magical Realism and Myth in Divakaruni's Novels
}

\section{Soundarya S S}

Assistant professor, Department of English, Rathnavel Subramaniam College of arts and science, Coimbatore, India

\begin{abstract}
The aim of the study is to portray that Magical realism acts an important factor because of its alternative belief system. Women are the crucial part of society, since their life depends upon someone else to run their life, they are fictional worlds and hence the Women Writers make him to enter into "real" world. Some familiar writers like Garcia Marquez's Macondo were one among them. It is said that the Magic comes naturally, as a simple, everyday occurrence. Magical realism is about mixing up things like ordinary with extraordinary, Fantasy with reality, reel with real. Hence Magical realism engages belief systems. It sets Magical events in realistic contexts about 'Real' and how it is exposed. It undermines our limitations we accept with or without any explanations. Hence Magical realist fiction is not "either/or but "both at once".
\end{abstract}

Keywords- Divakaruni's Novels, Magical realism acts, Garcia Marquez's Macondo.

\section{INTRODUCTION}

Literature is a body of written works similar to other arts like dance, music, drawing, euphony etc. However the name literature has been traditionally applied to the imaginative works of poetry, prose, drama, novel, and criticism. All these genres are differentiated by the imagination of the writer and also achieved the aesthetic excellence of executing.

Literature is classified according to a variety of systems including vocabulary, culture, tradition, and history. In the early stages literature was influenced by the Western art shape. The writers of the ancient period in India wrote on their own style.

A considerable amount of literature has grown between the North and the South Economic relations as observed particularly at the time of the Industrial Revolution and as obtained since the emergence of the independent 'South' states commonly grouped as the Third-World. Contemporary literature mostly gives importance on the issues that is raised in the international level. They include different themes, such as debt, poverty, unemployment, illiteracy, overpopulation, colonialism, religion, race, nationalism, human resources and information development, female participation, trade and so on. All these factors, however, interrupt the development process. Undoubtedly, literary works in Indian Writing in English are closely knit with most of these is sues. It is quintessential for the authors to acutely concentrate on issues in their works in a stylistic and simple way, so that the readers will enjoy through the language that was used.

Few of the women writers in modern India concentrated on the themes of Diaspora, Some of them concentrated on environmental issues, homosexuality and feminism, while others wrote on the basis of mental disorders and social issues of women. Most of the writers wrote in different languages that were later translated to English by themselves or by the others.

Most of the writers wrote on the basis of their native and such writings are said to be diasporic literature. A simple definition of diaspora literature would be works that are written by authors who live outside their native land. The term identifies a work's distinctive geographic origins. But diaspora literature may also be defined by its contents, regardless of where it was written. Diaspora implements a more neutral or even a more positive view than exile does. Diasporic literature may be mindful of the ancestral native land, but the nostalgia for it has lessened, if not disappeared. And diasporic literature is, moreover, engaged by the possibilities of the new location. Finally, it may be written well after the Babylonian exile by Jews who chose not to return. Diasporic living stops short of assimilation because the community still maintains its distinctive identity and its status as a minority people.

Many of the women novelists made their debut in the year 1990s. Anita Desai, wrote the novels Where Shall We Go This Summer? (1975), The Peacock Garden (1974), which became famous of its theme. Kiran Desai, was also one of the famous diasporic writer who wrote the works like Hullabaloo in the Guava Orchard and The Inheritance of the Loss, Meena Alexander wrote the works like Manhattan Music and Nampally Road which created an identity in her career Sunetra Gupta, wrote the novels on the basis of HIV and other related diseases and that made her different from other writers. Kamala Markandeya wrote the works on the basis of industrialization and ecological issues. Her novel Nectar in the Sieve became famous for such themes. Most of 
the writers wrote the novels in the way which revealed the injustice meted out to women in the male chauvinistic world. Their works were marked by an impressive feel for the language and an authentic presentation of post - independent India. They focused on the urban middle class scenario. The novelists of the latter half of the 20th century have begun to delineate the psychology of the characters and the complex environs which have greatly affected them. International marriages which were frowned upon earlier by a tradition bound society came to be accepted as a natural phenomenon. Divakaruni was born in Independent India. Later she moved to the United Land to pursue her degree. She completed her Post graduation in English at state university and Ph.D at the University of California at Berkeley. She was the president of MAITRI a free, confidential, referral non-profit organization based in the San Francisco Bay Area that primarily helps families from South Asia facing domestic violence, emotional abuse, cultural alienation, and human trafficking and she is currently a professor at Foothill College in California. Her works is recognized in more than 50 magazines and 30 anthologies. Her famous works are Arranged Marriage: Stories (1995), The Mistress of Spices (1997) ,Sister of My Heart (1999) The Unknown Errors of our Lives (2001,The Vine of Desire (2002), Queen of Dreams (2004) ,The Lives of Strangers (2005) ,The Palace of Illusions: A Novel (2008) ,One Amazing Thing (2010) ,Oleander Girl (2013).

Her works are included in the Best American Short Stories, The O'Henry Prize Stories, and two Pushcart Prize Anthologies. Her book of short stories, Arranged Marriage, won an American Book Award, the Bay Area Book Reviewers Award and the PEN Josephine Miles Award for fiction. The Mistress of Spices was on several Best Books lists, including the San Francisco Chronicle's 100 Best Books of the 20th Century, and was shortlisted for the Orange Prize.

Post colonialism encompasses a wide variety of approaches, and theoreticians may not always agree on a common set of definitions. On a simple level, it may seek through anthropological study to build a better understanding of colonial life from the point of view of the colonized people, based on the assumption that the colonial rulers are unreliable narrators.

Divakaruni has focused not just on the need for independence but also interdependence as an important aspect. The humanistic perspective and the need to rise above the shallow markers of discrimination have been emphasized repetitively in the novels of Divakaruni. Her novel One Amazing Thing for example conveys this theme of compassion and mutual understanding where diversity leads to unity and hybridity could be the hall marks of universality. Past is seen as intrinsically connected to the future of the individuals and the society at large.

The need to break the stereotypical attitude is the need of the situation both for the East and the West. Through her characters, the novelist has touched a chord by posing rhetorical questions in the course of the novels to ironically hint at the need for changed perspectives

Magical realism, or marvelous realism is a genre in literature that describes about the narrativefiction and, more broadly, art encompassing a range of subtly different concepts, expresses a primarily realistic view of the real world while also adding or revealing magical elements. In the recent times the theme of magic realism has emerged as a subgenre due to its prominent utilization as a leitmotif in contemporary novels while composition of myth and culture are historically used from ancient meter. Divakaruni has used mainly dream as proficiency to project the magical elements in her novels. The magical natural event in aspiration of the protagonists came true in living in her novels. Serpent Spices and Conch have the power to speak and they converse with protagonists like a human, the novelist has treated them, as if they have life and intelligence. The character does not doubt or question but accept, converse and reply to imaginary character. She has thus blended magic with realism in her novels.

Magic Realism' is a term coined by Franz Roz in 1925 to describe tendencies in the piece of works of certain German artists characterized by clear, static, thinly painted, sharp focus, look-alike, frequently depicting the imaginary, the improbable are the fantastic in a realistic rational manner. This term was first adapted in the United States at the New York museum of modern art. The magical realism in her work unfolds to understand the magical occurrence in one's life. Such as dream, thought transference and intuition portends the gluteus issues.

The magical elements in her novel prove that they portent reality as it has a tie with Psychology. Some scholars have said that magic realism is a natural outcome of postcolonial writing, which must make sense of at least two separate realities the reality of the conquerors as well as that of the conquered. Prominent among the Latin-American magic realists are the Colombian Gabriel García Márquez, the Brazilian Jorge Amado, the Argentines Jorge Luis Borges and Julio Cortazar, and the Chilean Isabel Allende. India is a land of culture and strong belief in superstitious notion. Preserving the culture is the prestigiousness of all countries. Divakaruni's novel is an evidence to prove it. 
Myth is a traditional story consisting of several events that are ostensibly historical, though often supernatural, explaining the origins of a cultural practice or natural phenomenon. In the period of Classical Sanskritic language, much material is preserved in the Sanskrit epics, The Ramayana and The Mahabharata. Besides theological system proper, the voluminous epos also provide a plethora of information about ancient Indian society, philosophy, culture, religion and in Hindu philosophy and service as parables and sources of devotion for Hindus.

The Mahabharata is the cosmos's longest epic in verse, running game to more than 30,000 lines. The mythical framework of her novels contributes to the creation of a female universe. The earthly concern of myth is essentially feminine in nature as opposed to the masculine. In her novels, there is an attempt to create new myth or demythification.

According to her opinion, the new myth symbolizes the feminine world where cleaning woman rescues other adult female without expecting backing from the men. She uses myth as a hold to companion herself with India. Divakaruni employs the myths and stereotypes surrounding the Indian adult female, which she consciously explores after her immigration and sets out to doubt and deconstruct. For instance, one of the myths that Divakaruni explores is the myth of widow hood.

The society, which is defined by men, deplores women whose husband is dead : Young or old the widow becomes a sexual, marginalized being who portends ill omen. In mythical the dominant feminine prototype is the chaste, patient, self-denying wife, Sita, supported by other anatomy such as Savitri, Draupadi, and Gandhari. When looking at these narration, silence or address can be a useful template to interpreting women's responses to patriarchal hegemony. Silence is a symbol or oppression, a characteristic of the subaltern condition, while speech signifies self-expression and liberty.

India is a land of culture and strong belief in superstitious notion. Preserving the culture is the prestigiousness of all countries. Divakaruni's novel is an evidence to prove it. Her novels portray the possibility for establishing a bicultural identity. Divakaruni's approach to ethnic identity is contingent with the scene of South Asian Diaspora that believes in the requirement of integrating the Red Indian heritage with its American experience. As cultural offshoots, the author heaps her novels with ritual, customs and practices pertaining to food for thought, garb, and the terminology of her native place. Indian society has managed to absorb and assimilate the divergent traditions, customs and consistency of knowledge and art forms from its invaders and these in turn have coalesced into a cosmopolite Indian culture of many religious practices, and a multitude of customs, feeling, linguistic process, art and architecture forms, etc., that can be identified easily.

Culture is a particular lodge or civilization especially considered in relation to its feeling, way of life or art. It is a particular system or group consists of the habit of the people in it and the way they generally behave. It consists of natural action such as the artistry and philosophy, which are considered to be important for the development of civilization and of people's minds. The ideal of the traditional, oppressed woman persisted in a culture permeated by religious images of virtuous goddesses devoted to their husbands, the Hindu goddesses Sita and Savitri serving as powerful cultural ideals of woman.

The changes and clashes caused by the impact of the Western culture have also been recorded by these novelists, in their thought-provoking novels. Dorothy, M. Spencer, Swami Vivekananda influenced Mahatma Gandhi vastly. He said that he wanted art and literature that can speak to trillion. And he did not want his family to be involved in English and his windows to be stuffed. He wanted the culture of all lands to be flown about his firm as freely as possible. The thoughts of both Vivekananda and Mahatma Gandhi had been activated simultaneously.

Divakaruni combines the unfamiliar, the female, Indian immigrant experience, with the familiar, urban life in America, shading the two into a magical narrative that relates a woman's plight as a foreigner in Southern Calif.

It is a realm where, having already experienced the pleasures of preparing, presenting, and partaking, one has subsequently shuffling it into a versatile medium for both spiritual and artistic creativity, a metaphor for diverse human experiences. As in the simple and complex conjunctions of food and art among the Hindus of Bengal, the traditional life of Bengal as portrayed in the novels of Divakaruni is rich in form, ritual, and aestheticism. In sacred and secular ceremonies, Bengalis have invested food with intricate symbolic implication. An extraordinarily active folk imagination tie on food images to create verse, paintings, and craft objects.

Divakaruni says in one of her interviews,

I want the culture to be presented without dilution. I have a deal of trust in my hearing - people understand through context a fortune of things that are not explained, she says, likely referring to the illustration when she mentions a Bengali give-and-take without rendering or an Indian 
cultural point of reference without explanation. (THE HINDU)

East-West encounters which is explained in terminus of hybridity in human relationship by postmodern. When the world has become a global village, no culture, or social club is pure or insular today. That is why Indian English fiction now takes characters, situations both from inside the country and abroad into its orbit and develops them.

\section{REFERENCES}

[1] https://bookriot.com/2018/02/08/what-is-magicalrealism/

[2] https://www.britannica.com/art/magic-realis m

[3] https://scholarblogs.emory.edu/postcolonialstudies/201 4/06/21/magical-realis m/

[4] https://penguin.co.in/book/uncategorized/one-amazingthing/

[5] https://www.npr.org/templates/story/story.php?storyId $=123977990$ 